\title{
Professionalism and the Use of Social Media
}

\author{
Nicole Mathies ${ }^{1}$ \\ ${ }^{1}$ Faculty of Medicine, University of Ottawa
}

\section{ABSTRACT}

Social media has rapidly expanded over the last few years. Active users know of the benefits and potential to do good but may be less aware of the insidious risks. When misused, social media can contribute to anxiety, depression, and even threaten physical safety. Of late, professionalism in social media has become a sensitive topic, especially in medicine. Ethical guidelines regarding the appropriate use of this constantly evolving platform have not been clearly implemented, resulting in significant uncertainty for both the consumers and governing bodies. In this commentary, I will discuss my personal experience with the controversial use of social media and propose novel methods to improve professionalism at the University of Ottawa.

RÉSUMÉ

Les médias sociaux se sont rapidement développés au cours des dernières années. Les utilisateurs actifs connaissent les avantages et le potentiel de bien faire, mais peuvent être moins conscients des risques insidieux. Lorsqu'ils sont abusés, les médias sociaux peuvent contribuer à l'anxiété, la dépression et même menacer la sécurité physique. Dernièrement, le professionnalisme dans les médias sociaux est devenu un sujet sensible, surtout en médecine. Les directives éthiques concernant l'utilisation appropriée de cette plate-forme en constante évolution n'ont pas été clairement mises en œuvre, ce qui entraîne une incertitude importante tant pour les consommateurs que pour les instances dirigeantes. Dans ce commentaire, je vais parler de mon expérience personnelle avec l'utilisation controversée des médias sociaux et proposer de nouvelles méthodes pour améliorer le professionnalisme à I'Université d'Ottawa.

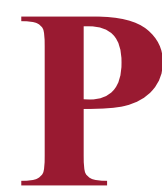

rofessionalism in medicine is often considered to be the foundation of a successful physician-patient relationship [1]. At the University of Ottawa, first-year medical students sign a declaration of professionalism, vowing to maintain a high standard of personal conduct and professional growth throughout one's medical career. While the vast majority of students maintain a professional behaviour in the clinical setting, social media remains a particular concern. Of late, the Faculty of Medicine has invested a great amount of time and effort to improve the professional behaviour of medical students while using social media platforms. In fact, the faculty created an online reporting system through the Professionalism website to encourage student professionalism through confidential peer and mentor feedback.

Recently, I was the subject of a complaint made anonymously through this reporting tool. Several months earlier, I had posted an Instagram photo of a social event during our Rural Community week, intended to thank the host for an enjoyable evening with local medical professionals and class colleagues. I commented on what had been so pleasant and wonderful that night; the food, the outing, and lastly, how the children had entertained us all with their antics. It was not a mean-spirited remark but because of the anonymous complaint, I now see that it was unprofessional in nature. My sarcasm inadvertently appeared to make fun of the children, and in turn our host's family. To this day, I deeply regret this mistake and have since deleted the comment. I believe such moments are important for growth and self-correction. This situation has prompted me to reflect further on the subject of professionalism because the reality is that for most people today, life is actively and publicly reflected through social media. My experience with unprofessionalism in social media is one example of hundreds [2]. Such incidents reflect deeper issues in today's society that should be of concern to the medical community.

As recently stated by our OMA President in the June 2017 Ontario Medical Review, "Our patients place great faith in us as partners in managing their care and wellness," and "it is our duty to speak up and tell the truth- to advocate for a better health care system for our patients and for our colleagues" [3]. Trust, unity and excellence are priorities of the OMA and so in keeping with

Keywords: Professionalism; Social Media; Medical Education; Patient-Physician Relationships; Communication 
these priorities, I will explore the issues of Social Media and Professionalism. In the Declaration of Professionalism contract signed by each first-year student, empathy and compassion are aptly cited as essential:"I will display compassion, empathy and concern for the well- being of all patients and their families" [4]. However, there is no mention of these values specifically with regards to our interactions with our peers, even though we are expected to be reciprocally helpful in each other's development.

Social media is here to stay and has vast potential to do good, as evidenced even by the teaching we as students have received by faculty to promote health education and awareness, discuss relevant issues, and to engage a broader audience. When misused, however, social media can become a far-reaching threat. Society and its mores have not had time to catch up to the rapid pace of social media expansion and etiquette rules have yet to be written. One damaging post has the potential to spread instantaneously to thousands of people online. We are also learning that freedom of speech does not necessarily apply to social media in its inherent risk of destroying reputations, careers and relationships [5].

The University of Ottawa defines professionalism in this way: "Professionalism embodies the relationship between medicine and society as it forms the basis of patient-physician trust. It attempts to make tangible certain attitudes, behaviours, and characteristics that are desirable among the medical profession. Although professionalism has been incorporated into most medical schools across North America, it remains rather difficult to define because it carries many connotations and implied meanings. What is certain, however, is that medicine is a moral endeavor which demands integrity, competence, and high ethical standards among other key attributes". [4]

In my opinion, this definition is limited. It should include guidelines on how to maintain professionalism between students. Just because a person gains admission to medical school does not necessarily mean that one is of a higher moral standards and incapable of intentional harming another. Competition, jealousy, stress, and other factors all contribute to the potential development of conflict and enmity within the student body. Consider the possibilities then, when an easily available opportunity is in place to complicate, disrupt and impair the mental health of the object of your dislike. Such is the risk of the online anonymous complaint system. The safety of anonymity that can bring about much good, also has an inherent potential for inflicting harm on each other, destroying trust and demoralizing the very community it is designed to encourage and protect. I have a personal experience to attest to this. Three months earlier during final exam week, two of my own Instagram photos were the subject of another anonymous complaint. As I spent a few days waiting to meet the Dean, I was anxious, worried and obviously distracted from my studies. I felt a deep erosion of trust, knowing that a colleague may have deliberately attempted to hurt me. That exam week was one of the most important moments of my life, yet it was filled with unnecessary distractions, insomnia and anxiety. Going forward, how does University of Ottawa's reporting system protect students in such situations?

Recent North American studies reveal alarmingly high rates of depression, anxiety, and suicidality within the medical school student population. Most alarming, these students did not manifest mental health symptoms prior to entering medicine [6]. While many of the stressors related to academic load, exposure to acute human illness, and physical fatigue cannot be avoided, it is imperative that medical schools attempt to minimize and not exacerbate such stressors. Policies must be in place to protect the mental wellbeing of medical students, preventing burnout while ensuring skills such as empathy, compassion and resiliency are optimized. In an internet age of potentially devastating websites such as "RateYourDoctor.com," where public comments can be freely written even if inaccurate, resiliency will be of utmost importance. We need to think outside of the box, creatively doing all that we can to graduate caring physicians with a preserved sense of humanity, despite the inevitable journey of desensitization that is present throughout medical school [7].

Change requires addressing these important system issues. In this instance, it can start with a detailed social media ethics guide for medical students. It means promoting a healthy and professional use of these powerful platforms, in order to lead the way in advocacy for our society. Efforts should also be made to revise the online anonymous professionalism reporting system to include instructions embracing accountability with suggestions such as: "We encourage you to speak directly to the person with whom you have professional concerns as a first step, as we believe this provides essential training in the skills of advocacy, conflict-resolution and compassionate, empathetic dialogue," and, "We as your faculty will gladly provide assistance if requested with the goal of fostering mutual re- 
spect. This site and its anonymity option should only be used as a last resort." A helpful and essential qualifier would also be, "What steps did you take when witnessing this situation to compassionately and confidentially support the growth in professionalism of your colleague?"

Lastly, I would take this entire process one step further and amend the Declaration of Professionalism to cite the importance of maintaining high standards of compassion and empathy between each other as students, not only to our patients and their families. I did not delete my Instagram account. I now have a better understanding of the inherent risks of social media in medicine, and that is a good start to maintain a professional behaviour. I also have a renewed hope that social media and its use is not out of the realm of physicians to make a positive influence in the medical community and society at large.

\section{REFERENCES}

1. Campbell EG, Regan S, Gruen RL, et al. Professionalism in Medicine: Results of a National Survey of Physicians. Ann Intern Med. 2007;147(11):795-802.

2. Chretien KC, Greysen SR, Chretien JP, Kind T. Online posting of unprofessional content by medical students. JAMA. 2009; 302(12):1309-15.

3. Whatley S. Raising Our Voice. OMR. 2017; 84:8

4. Seely J. What is Professionalism in Medicine [Internet]. Ottawa (ON): University of Ottawa, Department of Medicine cited 2017 Aug 20]. Available from: http://www.med.uottawa.ca/students/md/professionalism/eng/ what_is_professionalism.html.

5. Lambert KM, Barry P, Stokes G. Risk management and legal issues with the use of social media in the healthcare setting, J Healthc Risk Manag. 2012;31(4):41-7.

6. Sansone RA, Sansone LA. Physician suicide: a fleeting moment of despair. Psychiatry (Edgmont). 2009;6(1):18-22.

7. Grynspan D. Why I use Poetry in My Medical Teaching. UOJM. 2015;5(1):59 